\title{
Cash Holdings and Investment Levels: An Empirical Study from Listed Companies on Viet Nam's Stock Exchange
}

\author{
Hoang Thi Thuy ${ }^{1,2}$, Duong Thi Nhan ${ }^{2} \&$ Chen MiaoJian ${ }^{3}$ \\ ${ }^{1}$ South China University of Technology, China \\ ${ }^{2}$ Hanoi University of Mining and Geology, Viet Nam \\ ${ }^{3}$ Xingjian College of Science and Liberal Art, Guangxi University, China \\ Correspondence: Hoang Thi Thuy, South China University of Technology, China. E-mail: 2765884831@qq.com
}

Received: December 28, 2018

Accepted: January 26, 2019

Online Published: February 19, 2019

doi:10.5539/ijbm.v14n3p98

URL: https://doi.org/10.5539/ijbm.v14n3p98

\begin{abstract}
The study selected 410 companies on Viet Nam's Stock Exchange during the period from 2012 to 2016, with 2050 observations as a sample of research, to analyze the relationship between cash holdings and investment levels. The findings show that cash holdings has a positive effect on investment levels: the higher cash holdings, the greater investment level. Also, the results show that investment levels are affected by the return on total assets but not affected by the size of the company. The research is empirical evidence that contributes to the limited investment in research in Vietnam and is a reference for those interested in investing in Vietnam and managers in strategic policy formulation.
\end{abstract}

Keywords: cash holdings, investment, Viet Nam's stock exchange

\section{Introduction}

Investment is indispensable in the process of business development, so investment-related issues have attracted the attention of scholars around the world. According to the MM theory, capital markets are perfect, investment policies and corporate credit policies do not relationship exist. However, in fact, the investment policies of the company are affected by the company's internal cash flow. Fazzari et al. (1998) argue that the capital market is imperfect because of the asymmetric information problem. Therefore, corporate borrowing costs are higher than internal credit costs, domestic cash flow is not enough and enterprises will abandon the item with NPV $>0$, the investment level of the business decreased, resulting from ineffective investment, investment activities are lacking.

Besides, Jensen (1986) argues that managers who are tried to take advantage of the company's internal cash flow are willing to invest in NPV $<0$ projects, leading to the increase in corporate investment level, over-investment, ineffective investment. Because there are the "Agency problem" and "asymmetric information" in the company, company's cash Holdings and investment levels have a certain relationship. One of the reasons for the ineffectiveness of the investment phenomenon is that enterprises have typical financial resources such as excess cash flow or shortage. However, in recent years, the real situation of business investment of joint stock companies reflects the very low investment efficiency. In enterprises, there are ineffective investment activities such as over-investment or under-investment, especially in Vietnam.

Thus, the article wants to find out the current state of investment of companies participating in the Vietnam securities market, clarifying the relationship between the cash holding ratio and the investment decision of the enterprise. And it explains the factors such as the debt ratio, the size of the business, the time the company set up the enterprise, and the Return on total assets affect the firm's investment level, doesn't it? The results of the study can help the firm to clearly understand the relationship between cash holdings and investment level of the firm, whereby the firm has the plan to spend and store cash flows appropriately. The purpose is to improve the efficiency of investment activities of enterprises.

\section{Literature Review}

The Investment decision is one of the most important company's financial decisions because it creates the company's values. It also affects the process of success or failure of the Company (Huangming et al, 2003). 
From a financial perspective, investing is the process by which an investor spends a certain amount of assets to gain future benefits of the item investment items. For investing activities, the investment decision of the company is narrowly defined as the process by which the company spends a certain amount of capital funding in an investment item such as buying fixed assets or using costs to invest in any form to obtain benefits or increasing the amount of capital. The investment decision is a decision related to the value of assets and the value of each asset component including fixed assets and current assets (Wild et al.,2007). In the wide mean, to achieve a certain benefit in the future with the aim of maximizing profits, the company is willing to spend capital and spend on human resources to invest. The investment policy of the company is an essential part of the company's business process, making the right investment decisions will bring efficiency business.

According to Modigliani-Miller's (1958) study, in a perfect capital market, domestic capital and external capital are a perfect alternative. The company's investment decision is independent of its financial status. However, in reality, internal capital and market capital are not an ideal substitute, but the investment can be influenced by other factors such as financial leverage, internal cash flow, company's value, capital size (Arikawa et al, 2003). ZhangChao Lin (2018) argue that the cash holding ratio of each company has a significant impact on the company's investment. In the FHP study (1988), asymmetric information was argued and proved that cash flow strongly influenced investment. Ozkan (2002) also argued that cash holdings is an essential factor affecting the company's development thus the company needs to determine the amount of cash necessary. Scholars then investigated the relationship between the company's existing cash and investment decisions. But with different data collection scopes or different study periods, so the conclusions of the scholars are not the same: cash holdings has a positive, opposite or U-shaped effect on investment level.

Fazzari (1998) studies that asymmetric information problems create the company's financial constraints. When the financial situation of different enterprises will affect the investment of enterprises differently. Similarly, the results show that cash flow and investment are related in the same direction, the higher the amount of money, the higher the investment research activity (Faulkender, 2002). Too much cash flow will lead to ineffective investment (Jensen, 1986), insufficient cash flow will lead to financially restricted business and lead to under-investment, inefficient investment. Carpenter (2008), Degry et al. (2006), Makina et al. (2016) based on asymmetric information theory, in the study of the relationship between cash flow and investment show that cash flow has a positive effect on investment level or Nathalie et al. (2013) through the Tobin's Q measure of investment decision of the company, the research results also show that the relationship between investment and cash flow is the same direction. However, Jaggi et al (1999) pointed out that business investment opportunities and cash flows are the opposite, when the cash flow of the company is low and financial difficulties, internal cash flow is spent on normal business operations of the enterprise (Allyannis et al, 2004). But according to Stefan et al (2011), the cash flow and investment level are "U" shaped the relationship.

The study of the relationship between cash holdings and investment levels is mainly foreign in Vietnam is very limited. Therefore, based on the theory of relationship analysis of previous researchers and the practical situation of joint stock companies on Vietnam's Stock Exchange, to study the relationship between cash holdings and investment levels. The findings can explain the following issues: Has cash holdings a positive effect on investment levels? Clarify other factors such as debt ratio (Li et al,2010),Company's size (Zhu et al,2017)... how to affect the investment of enterprises.

\section{The Study's Hypotheses}

In the capital market, the corporate's investment decision should be independence with cash holdings. Someone researcher has introduced asymmetric information into the capital market, and it is the interpretation reasonable to that cash holdings affects the corporate investment. Therefore cash flow theory becomes to explaining corporate investment. The imperfect capital markets, The invest or's information about the quality and risk of the investment project is incomplete. It will make the external financing cost in the capital market of asymmetric information with the internal cost of the enterprise not the same, then they choose the reverse selection. When companies are financing in imperfect capital markets, an increase in corporate cash flows will result in higher levels of investment. This is because the increase in the level of the cash flow of enterprises will reduce the scale of financing through external capital markets, make to reduce the information cost of external financing, so as to promote the level of corporate investment. When the cash flow of external financing generated to insufficient, it will face a higher external capital cost, results the internal cash flow is preferred. Which means that companies use it to invest as much as possible, rather than borrowing or issuing new shares. If the company has insufficient internal cash flow and cannot go to the external capital market for financing, it will face the underinvestment problem. From the perspective of agency problem, The company evolves from management power which is separated from the power of ownership, the owner entrusts the assets to the agent who has the professional 
knowledge and ability to manage. In order to satisfy personal interests, managers should expand the scale of enterprises, the continuous improvement of output levels and additional consumption. In the case, for managers, the level of cash holdings available to the enterprise basically determines the investment expenditure and increases the corporate's investment level.

Until nowadays, the conclusion of the study of the relationship between cash holdings and investment levels still have different perspectives. The reason is that each scholar starts with various aspects, different studies or different methods of research, but most studies have suggested that as enterprises have increased cash flow, their financial resources increase, thus stimulating their investment of company. With the above analysis and argument the author makes the following assumptions:

Ho: Cash holdings has a positive effect on investment level.

\section{Factor Relations between Cash Holdings and Investment Level}

\subsection{Data and Models of Research}

Research data: Using the data from 2012-2016 of companies participating in the Vietnam securities market to carry out the analysis and empirical research.

The paper test the hypothesis base on the model of Jiang et al. (2003) to determine the relationship between cash holdings and investment level of enterprises. Figure 1:

$$
(\mathrm{I} / \mathrm{K})_{\mathrm{i}, \mathrm{t}}=\alpha_{0}+\alpha_{1}(\mathrm{CF} / \mathrm{K})_{\mathrm{i}, \mathrm{t}}+\alpha_{2} \operatorname{Lev}_{\mathrm{i}, \mathrm{t}}+\alpha_{3} \text { Growth }_{\mathrm{i}, \mathrm{t}-1}+\alpha_{4} \text { Size }_{\mathrm{i}, \mathrm{t}}+\mathrm{ROA} \mathrm{i}_{\mathrm{i}, \mathrm{t}}+\varepsilon
$$

Table 1. Variables used in the model

\begin{tabular}{|c|c|c|}
\hline Sign & Variable name & Measure \\
\hline \multicolumn{3}{|c|}{ 1. Dependency variable } \\
\hline $\mathrm{I} / \mathrm{K}$ & Investment decision & Investment (I) on Net Tangible Fixed Assets (K) \\
\hline \multicolumn{3}{|c|}{ 2.The explanation } \\
\hline $\mathrm{CF} / \mathrm{K}$ & Cash holdings & Cash and cash equivalents / Total fixed assets \\
\hline \multicolumn{3}{|c|}{ 3. Variable control } \\
\hline Size & Company's size & Firm's total assets logarithm \\
\hline Growth & The years of Establishment of Enterprises & The nutural logarithm of Years of Establishment of Enterprises \\
\hline Lev & Debt ratio & The firm's total debt diveded by total assets \\
\hline ROA & Return on total assets & Firm's operating Profit divided by Total Assets \\
\hline
\end{tabular}

\subsection{Research Results}

A summary of the descriptive statistics of the variables in the model is shown in Table 1 which indicates that the average value of the investment on fixed assets of Vietnamese enterprises in the sample is $0.7084 \%$, which is in the range from $-64.29 \%$ to $661.76 \%$. The cash holdings ranged from $0.00025 \%$ to $496.65 \%$, with the average value of $2.34 \%$.

Table 2. Descriptive statistics

\begin{tabular}{llrrrr}
\hline Variables & Obs & \multicolumn{1}{l}{ Mean } & Std. Dev. & \multicolumn{1}{l}{ Min } & \multicolumn{1}{l}{ Max } \\
\hline I/K & 2,050 & $0.7084 \%$ & $21.40 \%$ & $-64.29 \%$ & $661.767 \%$ \\
CF/K & 2,050 & $2.344 \%$ & $15.12 \%$ & $0.00025 \%$ & $496.65 \%$ \\
Lev & 2,050 & 0.51031 & 0.21608 & 0.012346 & 0.970611 \\
Growth & 2,050 & 2.99904 & 0.61234 & 1.302585 & 4.158883 \\
Size & 2,050 & 27.0705 & 1.48595 & 23.33036 & 31.92202 \\
ROA & 2,050 & 0.05259 & 0.07539 & -0.47157 & 0.783712 \\
\hline
\end{tabular}

The correlation coefficient between the variables is shown in Table 3. The correlation coefficients are less than 0.8 , the maximum coefficient is 0.3 , the maximum Variance inflation factor (VIF) is 1.39 . It can be said that high multicollinearity does not exist. 
Table 3. Correlation matrix between variable

\begin{tabular}{lrrrrrrr}
\hline Variables & \multicolumn{1}{l}{ I/K } & CF/K & Lev & Growth & Size & ROA & VIF \\
\hline IK/K & 1 & & & & & & \\
CF/K & 0.1113 & 1 & & & & & 1.01 \\
Lev & -0.0885 & -0.0488 & 1 & & & & 1.39 \\
Growth & -0.0719 & -0.0689 & 0.0485 & 1 & & & 1.02 \\
Size & -0.0013 & 0.0094 & 0.3068 & 0.023 & 1 & & 1.12 \\
ROA & -0.092 & 0.047 & -0.433 & 0.079 & -0.021 & 1 & 1.27 \\
\hline
\end{tabular}

Table 4 presents the results of the regression of relationship between cash holdings and investment level of enterprise based on equation (1) using ordinary least squate (OLS) estimation method, the fixed-effects regression model (FEM) and the random-effects regression model (REM) . However, when running the model due to the existence of unobserved variables in OLS, it should be used for FEM and REM modeling, but there is a variation in the variance The appropriate model that can correct this problem is the generalized least squares model (GLS). The results show that there exists a relationship between cash holdings and investment level of Vietnamese enterprises that can be observed in the FEM, REM, and GLS models, the coefficients are positive and statistically significant at $1 \%$. This result demonstrates that the relationship between internal cash holdings and investment in the business is the same relationship, the cash holdings in the enterprise increases, the investment level in enterprises also increased. It is appropriate with the current situation in the market. In the market economy, the economy is facing many difficulties, leading to difficulties in accessing capital from outside. Therefore, the internal cash holdings is the best alternative for other capital sources for new investment projects.

Table 4. Results of regression of the relationship between cash holdings and investment level of enterprises

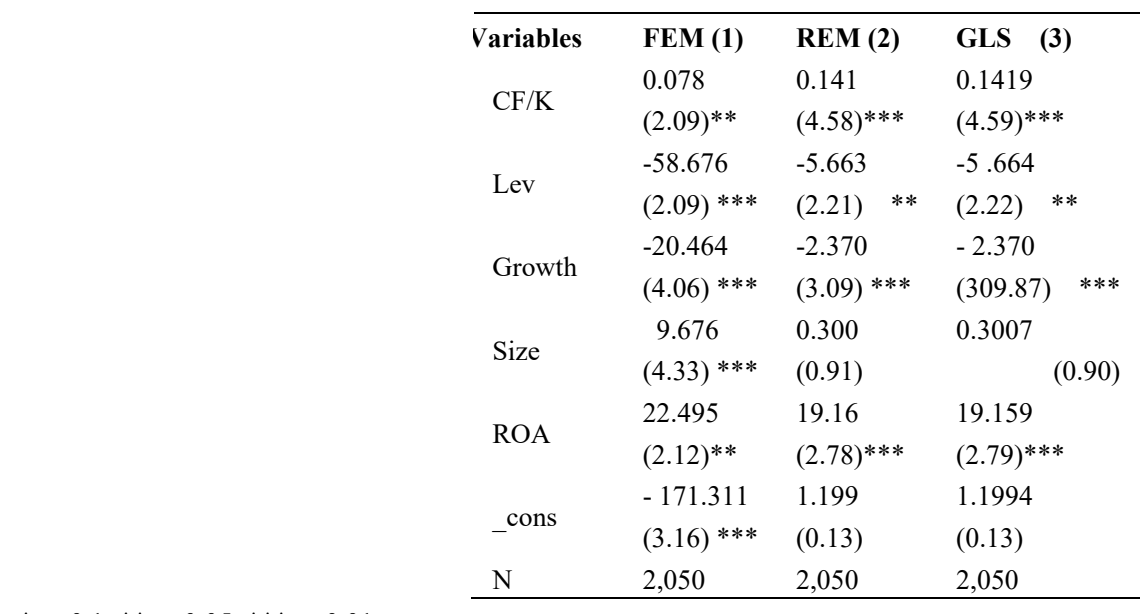

${ }^{*} \mathrm{p}<0.1 ; * * \mathrm{p}<0.05 ; * * * \mathrm{p}<0.01$

In addition, according to Table 4, the study results also show that the investment level of enterprises is affected by the ratio of debts, the number of years of establishment of the enterprise and the return on the total assets. The rate of debt and investment level is the reverse relationship, coefficient -5644 and statistically significant at $5 \%$, the higher the debt ratio, the lower the investment level. This finding is consistent with the results of the Nopphon study (2015). The coefficient between the return on total assets and the investment level is 19.159 and is statistically significant at $1 \%$, proving that the return on total assets has a positive effect on the investment level of the firm. When the return on total assets is high, helping to strengthen the confidence of outside investors, thereby attracting capital, will create more incentives to expand for investment. According to the results in Table 4, the results show that the relationship between the size of enterprises and the investment level is positive, but no statistically significant significance is found at $10 \%$, so it is not possible to conclude the relationship between the size and the investment level. 


\section{Conclusion}

The main study examines the relationship between cash holdings and investment level of the company, using the data of 410 companies participating in the joint-stock market of Vietnam from 2012 to 2016, the results show that the cash holdings has a positive effect on investment level. The test results show that the cash holdings and $\mathrm{p}$ the return on total assets are related in the same direction, the debt ratio and the number of years of establishment of enterprises have the opposite relationship. Enterprises with large or small cash holdings are more likely to experience over-investment or underinvestment, leading to reduced efficiency investment and reduced corporate value. As a result, enterprises need to improve their operating cash holdings, build cash flow projections plan for investment projects, assess the impact of cash flow on invest effect, build the information system on the effectiveness of using cash flow for investment decisions, contributing to increasing the investment efficiency of the investment decision of the company.

\section{References}

Allyannis, G., \& Mosumdar, A. (2004). The impact of negative cash flow and influential observations on investment-cash flow sensitivity estimates. Journal of Banking \& Finance, 28(5), 901-930.

Arikawa, Y., Miyajima, H., \& Saito, N. (2003). Investment and Governance: Evidence from Japan. University of Tokyo Press.

Carpenter, R., \& Guariglia, A. (2008). Cash flow, investment and investment opportunities: New tests using the UK panel. Journal of Banking and Finance, 32, 1894-1906.

Chirinko, R., \& Huntley, S. (1995). Why liquidity matters in investment equations. Journal of Money, Credit and Banking, 27(2), 527-547.

Degry, H., De Jong, A. (2006). Investment and internal finance: Asymmetric information or managerial discretion. International Journal of Industrial Organization, 24(1), 125-147.

Fazzari, S. M., Hubbard, R. G., \& Petersen, B. C. (1998). Financing Constraints and Corporate Investment. Boorkings Papers on Economic Activity, 1, 141-195.

Faulkender, M. W. (2002). Cash holdings among small businesses. Washington University, St. Louis, SSRNWorking paper.

Jaggi, G. (1999). An analysis of joint effects of investment opportunity set, free cash flows and size on corporate debt policy. Review of Quantitative Finance and Accounting, 12, 371-381.

Jensen, M. C. (1986). Agency Cost of Free Cash Flow, Corporate Finance, and Take-overs. American Economic Review, 76, 322-329.

Jiang, X. Z., Quan, L., Chen, J. F. (2003). Cash flow and corporate investment decision - An empirical study from the perspective of the size of corporations.

Ming, H., Ting, Z., Ling, Z. (2014). Research of manufacturing companys cash holdings impacts on performance under different institutional environment. The theory and Practice of Finance and Economics, 35, 59-64.

Li, J., Shi, C. W., Hua, Z. (2010). The inpact of debt financing on investment behavior companies: Evidence from China. International Journal of Digital Content Technology, 4(9), 17-26.

Nopphon, T. (2015). Over-investment and free Cash flow: Evidence from Thailand. Economics and Management ThaiLan, 15, 14-17.

Makina, L. W. (2016). The source of investment in cash flow sensitivity in manufaturing companies: is it asymmetric information or angency costs? Sourth African Journal of Economic and Managenment, 19(3), 398-399.

Miller, M. H., \& Rock, K. (1985). Dividend policy under asymmetric information. Journal of Finance, 2, 1053-1070.

Modigliani, F., \& Merton, M. (1958). Cost of capital, corprate finance and the theory of investment. American Economic Review, 4, 261-297.

Nathalie, M., \& Stefan, P. (2013). Investment and financing constraints. Journal of Accounting and Finance, 13(3), 200-215.

Oliner, S. D., \& Rudebusch, G. D. (1992). Sources of financing for business investment. The Review of Economics and Statistics, 643-654. 
Ozkan, A. (2002). Corporate Cash holdings: An Empirical investigation of UK Companies. University of York, SSRN Working paper.

Polk, C., \& Sapienza, P. (2008). The stock market and coporate investment: A test of catering Theory. Review of Financial Studies, 22(1), 187-217.

Richardson, S. (2006). Over - investment of free cash flow. Review of Accounting Studies, 11(3), 159-189.

Stefan, H., \& Marc, V. (2011). Financing constraints, cash flow, and corporate investment. Journal of Corporate Finance, 17, 1496-1509.

Zhang, C. L. (2018). Corporate cash holding, Financing constraints and Investment efficiency. Journal of Hubei University of Economics, 16(4), 14-21.

Zhaohui, Z., Xiaoyan, S., \& WenSheng, H. (2017). Top manangement team demography, investor sentiment, and the investment levels of listed companies. Journal of Accounting \& Economics, 1608-1625.

\section{Copyrights}

Copyright for this article is retained by the author(s), with first publication rights granted to the journal.

This is an open-access article distributed under the terms and conditions of the Creative Commons Attribution license (http://creativecommons.org/licenses/by/4.0/). 